\title{
Abraham Maslowin ja Carl Jungin uudistavan kokemuksen käsitteet minän kehityksen malleina
}

Reijo Miettinen

\author{
Kahden psykologin, Abraham Maslowin ja Carl Jungin, \\ teorioihin sisältyy useita yhteisiä perusolettamuksia. \\ Kumpikin asettaa tehtäväkseen ratkaista yksilöksi ja \\ persoonaksi tulemisen ongelman. Ratkaiseva käsite on \\ sisäinen kokemus. Aikuiskasvatuksen näkökulmasta \\ oleellista on se, että juuri humanistinen psykologia on \\ perustellut kokemusperäisen oppimisen käsitystä.
}

Kokemusoppimiseksi nimetyn kasvatustieteellisen suuntauksen eräänä perusteluna ovat humanistisen psykologian katsomukset ja tulokset. Suuntauksen perustuksen laskijoihin kuuluva David Kolb esittää Lewinin, Deweyn ja Piagetin ohella humanistisen psykologian ja Carl Jungin kokemusoppimisen perustelijoina (Kolb 1984, 15-16). Humanistinen psykologia on tarjonnut suuntaukselle kielen aikuisen ihmisen persoonallisuuden kehityksen ymmärtämiseksi. Tämä ilmiö on aikuiskasvatuksen ja elinikäisen oppimisen kannalta tärkeä.

Vaikka Abraham Maslowin humanistinen psykologia eroaa Carl Jungin analyyttisestä psykologiasta, niitä yhdistää keskeinen perusolettamus. Kumpikin kehittelee persoonallisuuden kehityksen kannalta ratkaisevan, sisäisen kokemuksen käsitettä. Tämän kokemuksen perusteluna on teoria ihmisen biologisesta olemuksesta. Eroistaan huolimatta kumpikin teoria edustaa romantiikan traditiota, joka näkee luonnon ihmisen identiteetin ja yksilöllisyyden lähteenä. Tässä artikkelissa tarkastelen, miten mainitut teoreetikot johtivat ja perustelivat persoonallisuus- ja kokemuskäsitteensä. Arvioin näiden käsitteiden perusteita kulttuuripsykologian lähtökohdista ja pohdin sen merkitystä aikuiskasvatustuksen ja aikuiskasvatustieteen kannalta.

\section{Humanistinen kokemuskäsite: ihmisolemusta etsimässä}

Humanistinen psykologia ei ole pelkästään ja ensijaisesti psykologinen koulukunta tai teoria- 
suuntaus. Se on terapiatyöstä kasvanut suuntaus, joka on kehittynyt maailmankatsomukseksi ja opiksi onnelliseksi tulemisesta. Humanistinen suuntaus syntyi psykologian kentässä 'kolmanneksi voimaksi', vastavoimaksi psykoanalyysille ja positivistiselle psykologialle, ennen kaikkea behaviorismille. Humanistisen psykologian ohjelman äänenkannattajana toimii JouRNAL OF HUMANISTIC PSYCHOLOGY -aikakauslehti. Sen perustivat vuonna 1958 Abraham Maslow ja Anthony Sutich ja se alkoi ilmestyä vuonna 1961. Lehden ensimmäisen numeron ohjelmanjulistus muotoili humanistisen psykologian peruspyrkimykset (esimerkiksi Wertheimer 1978, 740). Se mainitsee kuuden tutkijan nimet, joiden työ on luonut perustaa suuntaukselle. He ovat terapeuttista psykologiaa edustavat Abraham Maslow ja Carl Rogers, psykonaalyytikot Karen Horney ja Erich Fromm sekä persoonallisuuden - ja biologisen psykologian kentässä toimineet Kurt Goldstein ja Gordon Allport.

Ohjelmanjulistus toteaa, että lehden perustaneita ammattilaisia sitoo toisiinsa kiinnostus "niihin inhimillisiin kykyihin ja mahdollisuuksiin, joilla ei ole mitään järjestelmällistä sijaa positivistisessa tai behavioristisessa psykologiassa tai klassisessa psykonalyyttisessä teoriassa ts. luovuus, rakkaus, minä, kasvu, organismi, perustarpeiden tyydyttäminen, itsensä toteuttaminen, korkeammat arvot (...), psykologinen terveys jne.” Lehden ja liikkeen tavoitteena on nostaa tutkimuksen kohteeksi mainitun kahden suuntauksen laiminlyömä "ihmisen sisäinen elämä tavoitteena heidän voimavarojensa vapauttaminen itsetäyttymyksen maksimaaliseksi toteutumiseksi." Ohjelmanjulistus artikuloi suuntauksen keskeisen motiivin: luoda käsitteistö ja menettelytavat positiivisen kasvun, terveeksi ja onnelliseksi tulemisen ymmärtämiselle ja edistämiselle.

$\mathrm{H}$ umanistisen psykologian merkittävin teoreettinen hahmo on psykologi Abraham Maslow (1908-1970), jonka teorian tärkein käsite on "itsensä toteuttaminen". Tällä hän tarkoittaa ihmisen biologisen lajiolemuksen ja synnynnäisten mahdollisuuksien toteutumista yksilönkehityksessä.

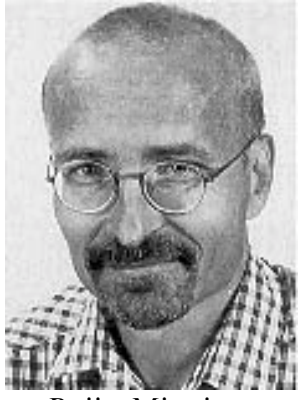

Reijo Miettinen

$\mathrm{T}$ arkastelen seuraavassa humanistista psykologiaa käyttämällä aineistona Maslowin tuotantoa. Hän edustaa yhdessä Carl Rogersin (19021987) kanssa humanistisen psykologian "ydintä”, terapeuttista psykologiaa. Maslow tunnetaan parhaiten motivaatioteoriastaan, joka perustuu viiden perustarpeen muodostamaan hierarkiaan. Hierarkiaa edetään alhaalta ylös. Vain fysiologiset ja turvallisuustarpeensa tyydyttänyt ihminen voi edetä älyllisten ja itsensä kehittämisen tarpeiden toteuttamiseen. Maslowin työ keskittyi ylimpään perustarpeeseen, itsensä toteuttamisen tarpeen tutkimiseen ja teoretisointiin. Hän kehitteli tämän käsitteen pohjalta kokonaisen elämän- ja arvofilosofian ja yhteiskunnan uudistusohjelman. Terveyden ja kasvun psykologian sekä yhteiskunnan uudistamisen perustana on biologisesti määräytynyt ihmisolemus, joka kuuluu alempien tarpeiden ohella itsensä kehittämisen tarve tai pyrkimys.

\section{Itsensä toteuttamisen käsitteestä elämänfilosofiaan}

Maslow omaksui itsensä toteuttamisen käsitteen psykologi Kurt Goldsteinilta (1878-1965). Goldstein halusi hylätä atomistiset selitysmallit, jotka tarkastelivat käyttäytymistä erillisinä reflekseinä, kykyinä tai vietteinä. Hän piti tutkimuskohteena KOKO ORGANISMIA (whole organism) ruumiillisine ja henkisine ominaisuuksineen. Terveelle organismille on ominaista ITSENSÄ TOTEUTTAMINEN, pyrkimys aktiivisuuteen sekä omien kykyjensä ja mahdollisuuksiensa toteuttaminen (Goldstein 1947, 222). 
$\mathrm{M}$ aslow kehitti itsensä kehittämisen käsitteestä oman tulkintansa, joka oli essentialistinen ja teleologinen: itsensä toteuttamisen tarve on ihmisolemuksen määräävä tendenssi, jonka toteuttaminen on ihmisenä olemisen väistämätön haaste. Maslowin tulkinta muistuttaa William McDougallin (1871-1938) biologista psykologiaa. McDougall katsoi, että kaikki elävät organismit käyttäytyvät tarkoitushakuisesti. Hän myös oletti, että kunkin eläinlajin olemuksen muodostavat sille ominaiset vietit (instincts). Eliöiden, mukaanlukien ihmisen käyttäytyminen voidaan selittää viettien avulla (McDougall 1912). Myös Maslow piti ihmisen perustarpeita synnynnäisinä vietteinä. Niiden tuntemus muodostaa pohjan inhimillisille arvoille ja yhteiskunnalliselle edistykselle (Maslow 1961b, 6):

"Jonkinlainen biologinen teoria, viettiteoria tai teoria perustarpeista (...) tarvitaan ehdottomasti hahmottelemani konseption rakentamiseksi. Lisäksi väitän, että nämä perustarpeet ovat luonteeltaan hyviä ja että niiden huolellinen tutkiminen antaa meille ne arvot, joiden avulla yhteiskunnat voivat kehittyä paremmiksi”.

Maslow lähtee tuotannossaan liikkeelle terapiatyöstä ja päätyy biologisen ihmisolemuksen teorian kautta maailmankatsomuksen muotoiluun. Erotan tässä siirtymässä viisi metodologista askelmaa.

\section{1) Itsensä toteuttaminen} tarve on välttämätön selitys terapiaprosessissa ilmenevälle paranemiselle

$\mathrm{M}$ aslow toteaa itsensä toteuttamisen käsitteen olevan välttämätön terveeksi tulemisen ja persoonallisuuden jatkuvan kehityksen ymmärtämiseksi. "Paine kohti terveyttä tekee terapian mahdolliseksi. Se on ehdoton sine qua non." Jos sellaista tendenssiä ei olisi, terapia olisi selittämätön ilmiö $(1955,5)$. Maslow toteaa, että perustarpeiden kriteerinä on se, että niiden tyydyttämättä jättäminen johtaa sairastumiseen. Siksi terapiatoiminta on erityisen sovelias ihmisen perustarpeiden tutkimiseen. Niin Maslowilla kuin Rogersillakin terapiatyöstä saatu kokemus muodostaa teoretisoinnin tärkeimmän perustan. Tämän lisäksi Maslow esittää neljä kirjallisuudessa esitettyä todistetta kasvun tai itsetäydellistymisen välttämättömyydestä $(1955,1)$ : 1) Kurt Goldstein katsoi itsensä toteuttamisen käsitteen tarpeelliseksi selittäessään vammautuneiden sotilaiden aivotoimintojen uudelleen organisoitumista. 2) Eric Fromm ja Karen Horney katsoivat, että neuroosin ymmärtäminen edellyttää täydellistymisen tendenssin olettamista. 3) Luovuuden, taiteen ja taidekasvatuksen teoria "edellyttää kasvun ja spontaanisuuden käsitteitä” (ml.). 4) Lapsipsykologian tulokset osoittavat, että terveet lapset nauttivat kasvusta ja uuden oppimisesta.

$\mathrm{M}$ aslowin teokset eivät sisällä potilasaineistojen esittelyä tai analyysia. Terapeuttisen kokemuksen käyttö rakentuu esimerkkeihin ja kokemusten kuvailevaan yleistämiseen. Seuraava Maslowin perustelu "tietämisen ja ymmärtämisen" tarpeelle kuvaa tätä kokemuksen hyödyntämisen metodia ja esitystapaa $(1970,49)$ : “Olen nähnyt MONIEN älykkäiden, rikkaiden ja vailla työtä olevien naisien ajautuvan älyllisen elämän rappeutumiseen. $\mathrm{Ne}$, jotka ovat seuranneet ohjettani ja omistautuneet johonkin arvoiseensa toimeliaisuuteen, osoittivat tarpeeksi usein paranemista vakuuttaakseen minut kognitiivisten tarpeiden todellisuudesta."

$\mathrm{M}$ aslowin perustelut itsensä toteuttami nen tarpeen olemassaololle eivät ole vakuuttavia. Paranemista voidaan selittää monilla tekijöillä, esim. oppimisella, yksilön ja hänen sosiaalisten suhteittensa muuttumisella, jne. Heidän tapaansa määritellä itsensä kehittämisen tarvetta koskee sama kuin McDougallin viettiteoriaa ja 1800-luvun kykyteoriaa. Sillä on tautologinen luonne. Aina kun havaitaan jokin käyttäytymismuoto, sen perustaksi nimetään tarve, vietti tai kyky (kts esim. Wollmann 1960, 183). Tarpeen nimeäminen ei tuo lisää havaittujen käyttäytymismuotojen ymmärtämistä. Tämä kritiikki oli Goldsteinin itsensä toteuttamisen käsitteen perusta. Hänen mukaansa on mahdotonta nimetä 
kulloisenkin käyttäytymismuodon perustaksi viettiä, koska nämä käyttäytymismuodot vaihtelevat organismin kokonaistilanteen ja -tilan, kypsyysasteen ja kokemuksen seurauksena. Siksi tarvitaan vain yksi selittävä tendenssi tai "korkeammanasteinen agentti", organismin paine toimia olemassaolonsa turvaamiseksi käyttämällä hyväksi ja kehittämällä niitä synnynnäisiä "potentiaaleja” ja kykyjä, joita sillä on (Goldstein 1995, 167). ${ }^{1}$

\section{2) Maslow antaa itsensä} toteuttaminen käsitteelle biologisen perustarpeen, “viettijäänteen" luonteen

Maslowin mukaan myös korkeammat tarpeet ovat "viettijäänteitä" tai "biologisia tendenssejä". Maslow toteaa (1951, 260-261):

“Tarpeet tietää, ymmärtää, muodostaa elämänfilofia, teoreettinen viitekehys, arvojärjestelmä ovat itsessään tahtoilmiöitä ja osa primitiivistä ja eläimellistä luontoamme. Sen tunnistamisella, että korkeammat tarpeet ovat viettejä (instinctoid) ja eläimellisiä, täsmälleen yhtä eläimellisiä kuin ruoan tarve, on monia seurauksia. (...). Jos eläimelliset tarpeemme nähdään saman luontoisina kuin korkeammat tarpeemme, kuinka sitten tiukkaa erottelua niiden välillä voidaan pitää yllä? Miten voimme jatkuvasti uskoa, että ne tulevat eri lähteestä?"

G oldstein torjuu viettiteorian $(1995,165-$ 172) sekä teleologisen selityksen (mts. 323). Hän liittää itsensä toteuttamisen käsitteen organismin olemassaolon turvaamiseen sen sopeutuessa ympäristöön (mts. 166) ja toisaalta biologisesti muodostuneiden dispositioiden tai mahdollisuuksien toteuttamiseen kypsymisen ja yksilönkehityksen kuluessa. Goldstein myös yhtyy amerikkalaisen sosiaalipsykologin Gordon Allportin (1950) käsitykseen, jonka mukaan ihmisen korkeammat motiivit ovat "funktionaalisesti autonomisia", riippumattomia biologisista viettitoiminnoista eikä niitä siksi voida selittää viettien avulla (1995, 160).

\section{3) Biologinen essentialismi:}

\section{Maslow nostaa itsensä}

toteuttamisen tarpeen

ihmisen tosiolemuksen

tunn usmerkiksi

$\mathrm{M}$ aslow tekee "itsensä toteuttamisen tarpeesta" ihmisolemuksen tunnusmerkin. Tätä kantaa voidaan kutsua biologiseksi essentialismiksi, koska se olettaa, että ihmislajilla on kiinteä, biologisesti määräytynyt olemus. Se on myös teleologinen näkemys korostaessaan, että tuohon olemukseen sisältyy tarkoitus ja mieli (Maslow 1959, 130): "Ihminen osoittaa omassa luonnossaan painetta kohti täydempää ja täydempää inhimillisyytensä toteutumista täsmälleen samassa luonnollisessa ja tieteellisessä mielessä kuin tammenterhon voidaan sanoa olevan paineessa kehittyä tammipuuksi, tiikerin voidaan nähdä työntyvän kohti tiikeriyttä ja hevosen hevoseläimenä olemista kohti.” Kun siis humanistiset psykologit käyttävät käsitettä AUTENTTINEN, tarkoittaa se ihmisen perimmäistä luontoa ilmaisevaa. Jos käyttäydyt autenttisesti tekosi kumpuaa sisältä - "sisäisestä ytimestä, todellisesta minästä” (Maslow 1959, 131).

Maslowin biologinen olemusoppi on metodologisesti ratkaiseva hänen oppirakennelmassaan. Se tarjoaa hänelle keinon tehdä itsensä toteutuksesta yleispätevä, kulttuurista riippumaton terveyden ja tosi-ihmisyyden mittapuu, josta voidaan johtaa hyvän elämän kriteerit ja yleiset moraalinormit. Sen pohjalle voidaan rakentaa elämänfilosofia ja yhteiskunnan uudistamisen ohjelma.

\section{4) Uuden moraaliopin rakentaminen nostamalla itsensä toteuttajien piirteet oikean elämän mittapuiksi}

Maslowin teorian rakentamisen neljäs askel on ihmisolemuksen tutkimisen kytkeminen inhimillisten arvojen ja elämänfilosofian löytämiseen. Teoksensa MotivaTion AND PERSONALITY johdannos- 
sa Maslow toteaa, että hän ei pyri pelkästään teorian luomiseen vaan, "uuden kokonaisvaltaisen elämänfilosofian" rakentamiseen (1970). Maslow toteaa, että hän on huolissaan ihmisen kohtalosta ja haluaa parantaa heidän osaansa (Maslow 1955, 2): "Itse asiassa joskus ajattelen, että psykologit voivat pelastaa maailman tai sitten sitä ei voida pelastaa lainkaan." Maslowin tieteellisen ohjelman olennainen osa on sellaisten arvojen löytäminen, joiden mukaan ihmiset voivat elää. Nämä arvot ovat löydettävissä havainnoimalla, kuinka lajin parhaat edustajat, itsensä toteuttajat elävät $(1959,128)$ :

"Väitän että itseään toteuttavien ihmisten vapaita valintoja voidaan tutkia kuvailevasti naturalistisena arvojärjestelmänä, jonka kanssa havainnoitsijan toiveilla ei ole mitään sijaa ts. kyseessä on tieteellinen menettely. En sano miten hänen pitäisi valita tämä tai tuo" vaan "terveitten ihmisten havaitaan valitsevan näin”. Tämä on sen kysymistä, mitkä ovat parhaitten ihmisten arvot."

Maslow kertoo vain epämääräisesti, millä kriteereillä hän valitsee parhaat ihmiset ja miten heidän valintojaan voidaan tutkia. Hän kertoo PERSONALITY AND MOTIVATION -teoksen viidennessä luvussa testanneensa 3000 opiskelijaa ja löytäneensä vain yhden itsensä toteuttajan. Historiallisista henkilöistä hän kelpuutti itsensä toteuttajiksi kaksi Yhdysvaltojen presidenteistä, Abraham Lincolnin ja Thomas Jeffersonin (1970, 152). Huomiot "hyvien ihmisten" valinnoista tai ominaisuuksista Maslow esittää, kuten hän asian ilmaisee "kokonaisvaltaisina vaikutelmina" ts. subjektiivisena kuvailuna itsensä toteuttajien ominaisuuksista.

$\mathrm{I}$ hmisolemuksen tutkimisessa moraalinen (kuinka pitäisi elää) ja tutkimuksellinen (kuinka itsensä toteuttajat elävät) muodostavat erottamattoman ykseyden. Maslowin tavoitteena on korkeampien arvojen biologinen perusteleminen (1976). Puhuessaan ihmisolemuksesta humanistit puhuvat elämisen arvoista (Maslow 1959, 126):

"Ihmisolennolla on sisällään paine (muiden paineiden ohella) kohti persoonallisuuden yhtenäisyyttä, kohti spontaania itsensä ilmaisua, kohti yksilöllisyyttä ja identiteettiä, totuuden näkemistä pikemminkin kuin sokeana olemista, kohti luovuutta ja hyvyyttä, ja paljon muuta. Ts. ihmisolento on rakentunut niin, että hän painautuu kohti täydempää ja täydempää olemassaoloa ja tämä merkitse painautumista kohti sellaista, jota useimmat ihmiset kutsuisivat hyviksi arvoiksi, painetta kohti mielenrauhaa, ystävällisyyttä, rohkeutta, tietoa, rehellisyyttä, rakkautta, epäitsekkyyttä ja hyvyyttä."

Itsensä toteuttajien ominaisuuksia havainnoimalla Maslow määrittelee erityiset B-arvot (sanasta Being), olemisarvot. Hän kutsuu niitä essentialistisen käsityskantansa mukaisesti myös "biologisiksi arvoiksi" $(1994,97)$ ja "lajiarvoiksi" (ml. 100) sekä kytkien ne moraaliin "viimekätisiksi arvoiksi" ja "hengellisiksi arvoiksi" (ml. 111) tai “ihmiskunnan arvoiksi" (1959, 132). Nämä ihmisen tosiolemukseen perustuvat arvot muodostavat ohjenuoran yksilöiden elämän uudistamiselle, organisaatioiden johtamisen ja yhteiskunnan insituutioiden muuttamiselle ihmisen kasvua (ihmisluonnon toteuttamista) tukeviksi (Maslow 1951, 263) "Itse asiassa koko kulttuurin parantamisen YDINKOHTA tulee olemaan antaa ihmisen sisäisten biologisten tendenssien toteuttaa paremmin itseään.” Teoria itsensä kehittämisestä sisältää arvofilosofian, maailmankatsomuksen ja terapeuttisen ohjelman. ${ }^{2}$

Olemisarvojen määrittely tapahtuu esittämällä itsensä toteuttajien myönteisiä ominaisuuksia koskevia laatumääreitä. Olemisarvoja on 14. Kolme ensimmäistä ovat totuus, hyvyys ja kauneus. ${ }^{3}$ Terveiden itsensä toteuttajien tutkimus on uuden, universaalin psykologian ja arvofilosofian alku.

\section{5) Kohti yleistä uskonnollista kokemusta: huippu- kokemukset ihmisen henkisen uudistumisen välineinä}

Maslowin teorian kehittelyn viides askel kytkee itsensä toteuttamisen ja olemisarvot uskonnolliseen kokemukseen. Ne viitoittavat tien kasvuun 
ja onneen ja tarjoavat aikamme ihmiselle moraalisen normiston ja elämänfilosofian. Maslow katsoi, että humanistisella psykologialla on tunnustuksellisia ja institutionalisoituneita uskontoja paremmat edellytykset ymmärtää ja vaalia aitoa uskonnollista kokemusta, jota hän teoriassaan kutsui huippukokemukseksi (peak experience) tai transsendentaaliseksi kokemukseksi (1994, 19). ${ }^{4}$

$\mathrm{M}$ aslowin sanoo, että hänen Itsensä toteuttajilla havaitsemillaan huippukokemuksilla oli yhtymäkohtia sekä taolaisuuden ja Zen-buddismin kokemus-käsitteeseen. Siksi hän kutsui huippu-kokemuksia myös taolaisiksi kokemuksiksi ja omaksui taolaisuuden aineksia uuden tietokäsityksensä perustaksi. Maslow uskoi ohjelmansa merkitsevän tieteen uudistamista siten, että se laajenee kattamaan monet niistä kysymyksistä, jotka on perinteisesti mielletty kuuluvaksi uskonnon piiriin. Tärkein näistä on arvojen tutkiminen ja niiden opettaminen ihmiskunnalle sekä sen osoittaminen, mikä on mystisen, elämää uudistavan kokemuksen merkitys ihmisenä olemiselle $(1994,17)$. Näin tiede ja uskonto yhdistyvät ja Maslowin oppi kasvaa elämänfilosofiaksi ja protouskonnoksi.

Artikkelissaan LESSONS FROM THE PEAK EXPERIENCES Maslow esittää kiteyttävän luonnehdinnan kokemusohjelmastaan, "huippukokemuksen" käsitteestä ja siitä, miten se kytkee toisiinsa idean biologisesta itsensä toteuttamisesta ja protouskonnollisesta kokemuksen (Maslow 1962b, 9): "Kun aloin tutkia terveyden psykologiaa poi-
min hienoimmat, terveimmät ihmiset, par-
haat ihmiskunnan eksemplaarit, mitä saatoin
löytää ja tutkin, minkälaisia he ovat. He oli-
vat hyvin erilaisia, hätkähdyttävän erilaisia
kuin keskimääräiset ihmiset. (...) Opin mo-
nia asioita näiltä ihmisiltä. Opin, että he ra-
portoivat, että heillä oli ollut jotain, jota
voidaan luonnehtia mystiseksi kokemuksek-
si, suuren innoituksen hetkiksi, pakahdut-
tavan onnen, ekstaasin tai autuuden hetkik-
si (koska sana onni voi olla liian heikko ku-
vaamaan tätä kokemusta).
Nämä hetket olivat puhtaan positiivisen on- nen hetkiä, joina kaikki epäilykset, kaikki pelot, kaikki estot, kaikki heikkoudet jäivät taakse. Tietoisuus minästä katosi. Kaikki erillisyys ja etäisyys maailmasta katosi, kun he kokivat samuuden maailman kanssa, yhtyvänsä siihen, todella kuuluvansa siihen sen sijaan että tarkkailisivat sitä ulkoa päin.

Ehkä kaikkein tärkeintä näiden hetkien raportoinnissa oli kuitenkin tunne siitä, että he olivat nähneet viimekätisen totuuden, asioiden olemuksen, elämän salaisuuden ikäänkuin verhot olisi vedetty sivuun. (...) Huippukokemusta voidaan pitää todella uskonnollisena kokemuksena sanan parhaassa, syvällisimmässä, universaalimmassa ja humanistisimmassa merkityksessä."

$\mathrm{H}$ uippukokemuksella on 15 piirrettä, joita Maslow kuvaa käyttäen runsaasti laatusanoja ja mielikuvia. ${ }^{5}$ Kolme ensimmäistä huippukokemuksen piirrettä ovat seuraavat. 1) Huippukokija (peaker) kokee itsensä kokonaisemmaksi eikä hajaantuneeksi. 2) Hän kykenee huippukokemuksessa sulautumaan maailmaan. Suurimmalla autonomian ja minuuden hetkellä hän ylittää itsensä ja kohoaa minuuden yli ja tuolle puolen. 3) Hän kokee olevansa voimansa tunnossa ja käyttävänsä kykyjään täysin ja parhaalla mahdollisella tavalla. Huippukokemukselle on ominaista ei-tahtomisen tila. Kokemuksesta tulee itsensä oikeuttava ja ihmisen pyrkimisiin liittyviä perusteluita kaipaamaton tila. Maslow lisää (1961a, 258): "Tällä tasolla olen kutsunut persoonaa jumalankaltaiseksi, koska useimmilla jumalilla ei ole katsottu olevan mitään tarpeita, heikkouksia tai puutteita."

Maslowin itsensä toteuttamisen teoriassa "huippukokemuksesta" tulee todellisen, autenttisen minän löytämisen ja kasvun tunnusmerkki. Se on ilmaisu siirtymisestä "pseudo-minästä todelliseen minään", oman objektiivisen biologisen luonnon, eläimellisyyden löytämisestä, oman lajin (lajiolemuksen) löytämisen ja sen kautta luontoon ja maailmankaikkeuteen kuulumisen kokemiseen (s.95). Tämän saavuttamisessa humanistisen terapian ja transsentaalisen mietiskelyn menetelmillä on paljon yhtymäkohtia. Maslow luonnehtiikin terapiaansa taolaiseksi terapiaksi. 
Maslowin suuressa synteesissä biologinen oppi ihmisolemuksesta ja uskonnollisesta huippukokemuksesta yhdistyvät universaalin moraalin tarjoavaksi maailmankatsomukseksi sekä ihmisen ja yhteiskunnan uudistamisohjelmaksi. Colin Wilson, itsekin humanistinen psykologi, toteaakin, että Maslowin myöhäistuotannon teksteissä puhuu enemmän maallikkosaarnaaja kuin psykologi (Wilson 1972,199).

\section{Jungin kokemuskäsite: yhteys lajihistoriallisen piilotajunnan arkkikuviin}

$\mathrm{E}$ i ole sattuma, että Carl Jungin psykologia mainitaan usein humanistisen psykologian rinnalla kokemuksen käsitteen perustelijana ja kehittelijänä. Vaikka Jungin oppi on lähtöisin humanistien kritisoimasta psykoanalyysista, se sisältää monia samoja piirteitä Maslowin ohjelman kanssa. Myös Jungin oppi on syntynyt ja kehittynyt terapian kontektissa ja pyrkii laajentumaan maailmankatsomukseksi. Jung näkee psykologian tehtäväksi tarjota vaihtoehto ihmisille, jonka rationaalisuuteen pyrkivä tiede ja institutionalisoitunut uskonto on jättänyt ahdinkoon. Myös Jungille sisäinen kokemus on henkisen kasvun ja ihmiseksi tulemisen tärkeä perusta. Maslowin lailla Jung sanoo: persoonallisuus on tao (Jung 1991, 113) "Taon löytäminen merkitsee täydellisyyttä, kokonaisuutta, täytettyä kutsumusta, alkua ja päämäärää ja kaikissa oloissa olevan synnynnäisen päämäärän täydellistä toteutumista."

J ung kirjoitti useita teoksia, joissa hän analysoi aikamme ihmisen kriisiä ja hahmotteli oppia yksilöllistymisestä piilotajuisen kokemuksen kautta ratkaisuna tähän kriisiin. ${ }^{6}$ Näissä teoksissa Jung näki valtion ja kirkot massaorganisaatioina, jotka keskinkertaistavat ihmisen ja tukahduttavat yksilöllisyyden vaatimalla alistumista järjestelmäänsä. Kommunismin tai yhteisöllisyyden periaate, jota sekä valtio että kirkko edustavat, uhkaa ihmisen yksilöllisyyttä ja aitoa sisäistä kekemusta. Yksilöstä tulee "valtion ja tilastojen funktio", massayhteiskunnan kansalainen. Institutionalisoitunut uskonnon harjoittaminen on kol- lektiiviseen mentaliteettiin sulautumisen muoto. Yksilö alistuu ulkoiselle auktoriteetille. Sen sijaan aito uskonnollisuus "ilmaisee subjektiivista suhdetta joihinkin metafyysisiin ja ylimaallisiin tekijöihin" (1958, 31). "Siksi hän tarvitsee sisäisen, transsendentin kokemuksen, joka ainoastaan voi suojata hänet muutoin väistämättömältä sulautumiselta massaan" (mts. 34). Moderni psykologia oppina henkisyydestä ja itsenäisestä psyykkisestä todellisuudesta voi tarjota vaihtoehdon vapauttavan, transsendentin kokemuksen muodossa. Jungille mystisten, vapauttavien kokemusten perustelu oli yhteyden saaminen piilotajuntaan, jonka hän määritteli myös lajihistorialliseksi tai kollektiiviseksi piilotajunnaksi. Piilotajunnassa yksilö saa yhteyden primitiiviseen, väärentymättömään inhimilliseen, ihmiskunnan esikristillisen menneisyyden arkkikuviin.

$\mathrm{B}$ rittiläinen tutkija Richard Noll $(1996,1997)$ on tehnyt uraauurtavaa työtä analysoidessaan Jungin opin aatehistoriallista taustaa. Noll osoittaa, miten Jungin lajihistoriallisen ja kollektiivisen kokemuksen käsite on ymmättävissä vain aikakautensa kulttuuristen ainesten ja maailmankatsomuksellisten pyrkimysten ilmaisuna. Jungin taustana ja kasvupohjana oli 1800-luvun lopun Lebensphilosophie, elämänfilosofia, joka korosti suoran kokemuksen ja intuition merkitystä rationaalin ajattelun sijaan. Tätä suuntausta edustivat mm. Friedrich Nietzsche ja Henri Bergson. Toinen Jungin ajattelun kasvupohja oli 1800luvun romanttinen luonnonfilosofia. Jungin kollektiivisen piilotajunnan käsitteen perustana oli saksalaisen biologin Ernst Haeckelin evoluutiobiologinen teoria (Haeckel 1912). Haeckel muotoili eri eläinlajien sikiönkehityksen vertailuun perustuvan rekapitulaatioteorian, jonka mukaan yksilönkehitys toistaa lajinkehityksen kulun. Teoksessaan MAAILMANARVOITUKSET Haeckel esitteli luonnontieteiden kehitykseen perustuvan monistisen maailmankuvan sekä "totuuden, hyvän ja kauneuden uskonnon". Teoksessaan Haeckel esitti myös ajatuksen "lajikehityksen psykologiasta" ja "sielun lajikehityksestä"(1912, 160$161){ }^{7}$

Jung omaksui tämän idean Haeckelilta yhdistäen sen psykoanalyysin teoriaan alitajunnasta (kts. 
Noll 1996, 51-54). Aivan kuten biologinen evoluutio heijastuu sikiön kehitysvaiheissa, ihmiskunnan historia on kerrostuneena psyykkeessä. Piilotajunta edustaa esikristillisen pakanallisuuden arkkityyppisiä kokemuksia. "Alitajunnan tuotteet liittyvät myyttiseen. (...) Sielulla on tiettyyn pisteeseen asti historiallisia kerrostumia, joista vanhin vastaa piilotajuntaa". Piilotajunta jakaantuu kahteen osaan: henkilökohtaiseen ja epä- tai ylipersoonalliseen piilotajuntaan. "Viimeksi mainittua nimitämme myös kollektiiviseksi piilotajunnaksi (...), koska se eroaa henkilökohtaisesta ja on aivan yleinen ja sen aiheita voidaan tavata kaikkialla" (Jung 1966, 86).

$\mathrm{R}$ omanttisen luonnonfilosofian ja vitalismin tapaan piilotajunta edusti myös kulttuurin keinotekoisten muotojen alla olevaa luonnollista ja siksi tosi-inhimillistä, ihmislajille yhteistä ja yleistä. Jung puhuu "eläimen pyhyyden ja ethoksen uudelleensaavuttamisesta" ja "ekstaattisista viettivoimista", jotka liittyvät kulttiin ja salaiseen myyttiin (Noll 1996, 188). Saksan ja Keski-Euroopan 1800-luvun erityinen aatemaailma tekee ymmärrettäväksi sen määreiden kudelman, jonka Jung antaa kokemukselle: lajihistoriallinen, biologinen, luonnollinen, alkuperäinen, pakanallinen, arjalainen, pyhä, transendentti.

$\mathrm{U}$ nessa ja poikkeustilanteissa kollektiivinen piilotajunta ilmenee mielikuvina. Jung myös kehitteli teosofian esikuvan pohjalta aktiivisen kuvittelun menetelmää, jonka avulla yksilö voi luoda yhteyden kollektiiviseen piilotajuntaan. Kollektiivisen piilotajunnan todisteeksi Jung ja hänen työtoverinsa esittivät esimerkkejä potilaittensa mielikuvista, jotka vastasivat pakanallisen menneisyyden myyttikuvia.

Kollektiivinen piilotajunta ja sen lajihistorialliset arkkityypit muodostavat Jungin epistemologian sekä persoonaksi ja yksilöksi kasvamisen lähteen. Jungin mystisessä totuudessa yhdistyy romanttinen biologismi, joka kytkee toisiinsa viettienergian ja arkkikuvat sekä idealisoidun primitiivisen, mytologisoidun muinaisen ja arjalaisen menneisyyden. Huippukokemuksessa, harhassa, unessa tietoisuus saa yhteyden kollek- tiivisen piilotajunnan arkkikuviin (1958, 82): "Inhimillinen tieto koostuu olennaisilta osiltaan jatkuvasta sopeutumisesta sellaisten alkuideoiden kaavioihin, jotka on annettu meille a priori. Nämä vaativat modifikaatiota, koska ne alkuperäisessä muodossaan kuuluivat arkaaiseen elämänmuotoon, mutta eivät enää differentitoituneeseen ympäristöön.”

\section{Yksilöksi ja kokonais- persoonaksi tuleminen}

Tung kutsuu yksilöksi tulemista individuaalisaatioprosessiksi. Hän tarkoittaa yksilöllisyydellä $(1995,436)$ "kaikkein sisintä, kaikkein viimeisintä ja ylittämättömintä ainutlaatuisuuttamme, omaksi itseksi tulemista. Individualisaatiota voidaan kutsua myös "itseksi tulemiseksi" tai "itsensä toteuttamiseksi." Individualisaatio merkitsee erottaumista ja vapautumista laumasta ja perinteestä. Tämän vapautumisen tien perustana on sisäinen ääni tai kutsumus (1983, 205 ja 203):

"Se mitä kutsumme persoonallisuudeksi on suuri ja mysteerinen ongelma. Ongelma näyttää näin ylittävän inhimillisen rajat alueelle, jota olemme tunteneet pyhällä nimellä. Kuten huomaatte, minun on viitattava "sisäiseen ääneen”, kutsumukseen ja määriteltävä se objektiivis-psyykkisenä tekijänä (...) Jokaisella yksilöllä on oma lakinsa synnynnäisenä itsessään ja jokaiselle on teoreettisesti mahdollista seurata tätä lakia ja tulla persoonallisuudeksi, ts. saavuttaa kokonaisuus. (...) “

Kokonaisuus ja integraatio, jota individualisaatioprosessissa tavoitellaan merkitsee psyyken kahden perusosan tietoisuuden (ego) sekä piilotajunnan riittävää tasapainoa. Jung sanoo: olemme tilanteessa, jossa "mustan pedon päällä on sivistyksen kuori” (1966, 123). Kumpikaan ei saa hallita tai alistaa toista. Suhde on samanaikaisesti konfliktin ja yhteistyön läpitunkemaa. "Tietoisuuden on puolustettava järkeään ja suojeltava itseään ja kaoottiselle piilotajunnalle on annettava mahdollisuus saada oma tiensä - niin 
paljon kuin sitä voimme kestää” 1983, 225). Tietoisuus rakentuu psyyken vanhemmalle kerrostumalle piilotajunnalle, jonka aineksista se muokkaa yksilöllisen tiensä. Kollektiivisella piilotajunnalla on Janus-kasvot (1983, 216): toisaalta se viittaa menneisyyteen, esi- ja lajihistorialliseen vaistojen maailmaan, toisaalta se ennakoi tulevaisuutta. Siksi yksilöksi tulemisen lähteet löytävät lajihistoriallisesta piilotajunnasta. Jung rinnasti individualisaatioprosessin alkemistien kokeisiin: kollektiivisen piilotajunnan arkkityyppisen ainesten työstäminen tietoisuudesta rinnastuu aineen olomuodon muuttumiseen (Jung 1983, 208).

I hmisen tietoisuudelle ja itsetietoisuudelle on tärkeää löytää "alkukuvat uudelleen” ja estää tietoisuuden ja alkukuvien viettienergian erillisyys, vastakkaisuus ja ristiriita. Yksilö tulee tietoiseksi lajihistoriallisesta menneisyydestään ja kasvaa persoonaksi. Välitön yhteys primitiiviseen, lajihistorialliseen piilotajuntaan on näin henkisen vapautumisen tie, uudelleensyntymisen ja yksilölliseksi tulemisen tie, vastaus itseään etsivälle nykyjan ihmiselle (Jung 1966, 145). Koska lajihistorialliset alkukuvat vaativat mytologiaan perehtyneen tulkitsijan, tapahtuu vapahtuminen parhaimmin jungilaisessa terapiassa.

$\mathrm{J}$ ungin mutkikkaan mytologian, biologian, rotuhistorian ja psykologian yhdistävälle opille "kollektiivisesta piilotajunnasta" on mahdollista esittää luonteva selitys. Lajihistoriallisesti yhteinen välittyy uudelle sukupolvelle osittain tietoisesti, osittain tiedostamattomasti kulttuuriperintönä. Yksilö omaksuu sosialisaatiossaan symboleja, ajattelu-, toiminta- ja kokemistapoja. Hänen alitajunnassaan yhdistyvät ja muuntuvat ne moninaiset kulttuurin ainekset, jotka hän on yhteisöllisessä vuorovaikutuksessa omaksunut. Tässä prosessissa ei ole mitään mystistä tai yliluonnollista. Jung kuitenkin torjuu kulttuurihistoriallisen selityksen mahdollisuuden ja edellyttää jonkinlaisen biologisen mekanismin olemassaoloa (1938,111-112): "Vaikuttaa siltä, että tiedostamaton mieli on työskennellyt saman ajattelun tien mukaan, joka on yhä uudestaan ja uudestaan ilmaissut itsensä parin viime vuosituhannen kuluessa. Sellainen jatkuvuus voi olla ole- massa vain jos oletamme tietyn tiedostamattoman ehdon, jota biologinen perimä kantaa." Jungin ajatus lajihistorillisesta muistijäljestä biologisena ilmiönä vastaa lamarckilaista käsitystä periytyvyydestä eikä ole ymmärrettävissä sen valossa, mitä tiedämme geenien välityksellä tapahtuvasta perinnöllisyydestä. ${ }^{8}$

\section{Johtopäätökset}

$\mathrm{M}$ aslowin ja Jungin teorioihin sisältyy useita yhteisiä perusolettamuksia. Kumpikin asettaa tehtäväkseen ratkaista yksilöksi ja persoonaksi tulemisen ongelman. Kumpikin etsii ratkaisua biologiseksi ymmärretystä ihmisolemuksesta. Kumpikin olettaa, että on olemassa erityinen kokemuksen laji, jonka kautta persoonaksi tai yksilöksi kasvaminen voi tapahtua. Maslowilla tämä kokemus oli huippukokemus, Jungilla yhteys primitiiviseen kollektiiviiseen piilotajuntaan. Kumpikin ymmärsi tällaisen kokemuksen henkisen kehityksen lähteenä ja vaihtoehtona teolliselle massayhteiskunnalle ja tunnustukselliselle, institutionalisoidulle uskonnolle. Kumpikin piti tällaista kokemusta myös mystisenä ja uskonnollisena kokemuksena ja rinnasti minäksi tulemisen buddhalaisuuden Taoon, sisäisen kokemuksen tiehen.

$\mathrm{K}$ umpikin oli omalla tavallaan elitistinen. Maslow löysi vain harvat ja valitut itsensä toteuttajat. Jung katsoi Nietzchen tapaan, että vain poikkeusyksilöt pystyvät irottautumaan tavanomaisuudesta ja tulemaan todellisiksi yksilöiksi, oman tiensä kulkijoiksi.

Samalla on todettava Maslowin ja Jungin erilaisuus. Maslowille sisäinen kokemus on puhtaasti individualistinen ilmiö. Jungille kollektiivisen piilotajunnan käsite tuo kokemukseen historiallisen ja yhteiskunnallisen ulottuvuuden, vaikkakin se esiintyy hänellä mystisessä muodossa, kollektiivisena piilotajuntana.

ekä Maslow ja Jung edustavat psykologiassa 1800-luvun romantiikan perinnettä. Modernin minä- ja yksilökäsitteen syntyä koskevassa tutkimuksessaan kanadalainen filosofi Charles 
Taylor määrittelee romantiikan panoksen modernin minäkäsityksen synnyssä. Romantiikka nosti luonnon minän kehityksen sisäiseksi lähteeksi. Rosseau oli ensimmäinen, joka määritteli alkuperäisen - turmeltumattoman ja luonnollisen kasvun ja kehityksen lähteeksi ja mittapuuksi. Jungin teoria on esimerkki romantiikalle ominaisesta primitiivisen, myyttisen ja biologisen yhdistämisestä minän lähteeksi. Taylor luonnehtii romantiikan käännettä seuraavasti $(1989,368$ 369 ja 374):

"Perinteistä rationalismia, traditiota ja harmoniaa vastaan romantikot nostivat yksilön oikeudet, mielikuvituksen ja tunteet (..). Sisäisen äänen tai impulssin idea - idea siitä, että löydämme totuuden sisältämme ja erityisesti tunteestamme - oli romantiikan kapinan eri muotoja perusteleva käsite (...). Jos yhteys luontoon toteutuu sisäisen äänen tai impulssin kautta, silloin voimme tuntea luonnon vain artikuloimalla sen, mitä löydämme sisältämme. Tämän toteutuminen meissä kussakin on itseilmaisun muoto “

Taylor toteaa, että tähän käsitykseen sisältyi lisäksi radikaalin itsemääräytymisen ja riippumattomuuden ajatus. Hän pohtii romanttisen käsityksen seurauksia etiikan ja demokratian kannalta (1991). Itsemääräytymisen idea korostaa ainutkertaista erottumista muista ja yhteyttä minuuden sisäiseen lähteeseen. Taylorin mielestä identiteetti ei kuitenkaan ole monologinen ilmiö Đ keskustelua sisäisen äänen kanssa - vaan rakentuu dialogissa muiden ihmisten kanssa. Identiteetin lähde on suhde merkittäviin muihin ihmisiin. Identiteetti ankkuroituu tarpeeseen tulla kanssaihmisten hyväksymäksi ja saada tunnustusta. Taylor katsoo, että sisäiseen lähteeseen perustuva minän autenttisuuskäsite aliarvioi dialogisuuden merkityksen ja on omiaan johtamaan atomismiin, yksilön etääntymiseen yhteisöllisistä suhteista ja vastuusta $(1991,34)$.

Kulttuuripsykologian näkökulmasta romanttisbiologisen näkemyksen rajoitukset liittyvät minän ja kulttuurin väliseen suhteeseen. Maslowin ja Jungin käsityksissä kulttuuri on viime kädessä rajoittava, negatiivinen, ja yksilöllisyyttä alistava tekijä. Maslowille kulttuuri on biologisen ihmisolemuksen toteutumisen kehys, joka on muutettava tuon olemuksen toteuttamista palvelevaksi, eypsykiaaniseksi maailmaksi. Jungille kulttuuriin sopeutuminen on massaihmiseksi tulemista ja yksilöllisyyden toteutumatta jäämistä. Yhdenmukaistavan nykykulttuurin vastapainoksi Jung asetti myyttisen ja elinvoimaisen menneisyyden arkkikuvat minän kehityksen lähteenä.

Kulttuuripsykologia näkee kulttuurin monitahoisemmin ja myönteisemmin. Se on ihmistymisen perusta, voimavara ja luovan toiminnan välttämätön välinearsenaali. Kulttuuripsykologia näkee yksilöllisyyden kehityksen mahdollisuuden kulttuurin uudistamiseen osallistumisessa. Tämä osallistuminen edellyttää dialogia ja osanottoa yhteisöllisen toimintaan ja samanaikaisesti kunkin yksilön erityistä ja yksilöllistä panosta.

Kulttuurin ja ympäristön muuttamiseen perustuvalla ihmis- ja oppimisnäkemyksellä on filosofinen ja historiallinen perinteensä. Mm. Giambattista Vico (1668-1744) ja Karl Marx esittivät, että ihmisen olemus on luontoa ja ympäristöä muokkaavassa toiminnassa ja kulttuuriartefaktien luomisessa, käytössä ja kehittämisessä. Ihmisolemus on ymmärrettävissä vain osana yhteisöllistä luomistyötä, ihmisen kulttuurihistoriaa. John Deweyn kokemuskäsitteessä yksilön kehitys ja maailman muuttaminen - ympäristön rekonstruktio liittyvät erottamattomasti toisiinsa.

Oppimisen tutkimuksessa kulttuurista näkemystä edustavat kontekstuaaliset, tekemisen ja oppimisen yhteisöjä korostavat näkemykset. $\mathrm{Ne}$ katsovat, että yksilön oppiminen ja kehitys toteutuu yhteisöllisessä käytännössä (Wenger 1998). Kulttuurin välineiden kehittäminen ja luomistyö on samalla kuitenkin vastuun ottamista yhteisöstä ja sen panoksesta yhteiskunnalle. Kehittävä työntutkimus on lähestymistapa, joka on kiinnostunut tutkimaan yksilön oppimista osana työyhteisön toiminnan olennaisten ongelmien ratkaisua sekä uusien työvälineiden ja toimintatapojen luomista (Engeström 1995).

Miten humanistinen käsitys on heijastunut aikuiskasvatuksen piirissä? ${ }^{9}$ Se on perustellut ko- 
kemusoppimiseksi kutsuttua oppimiskäsitystä useilla tavoilla. Ensinnäkin se on luonut perusteita tämän näkemyksen metodologiselle individualismismille. Se on tarjonnut tuolle näkemykselle yksilöllisyyden ensijaisuutta perustelevan kielellisen kerrostuman: autenttisuus, persoona, ainutkertaisuus, itsensä toteuttaminen, todellinen minä jne. Se on tuonut Carl Rogersin terapeuttisen näkemyksen opettajasta "fasilitaattorina", sallijana, synnynnäisen kasvupotentiaalin, persoonaksi tulemisen ja kokemisen ihmeen puutarhurina (Rogers 1979). Humanistisen psykologian kasvun, kehityksen ja itsensä toteuttamisen sanoma antaa elinikäisen oppimisen koulutuspoliittiselle käsitteelle soveliasta arvotaustaa.

\section{$\mathrm{S}$} aattaa olla, että aikuiskoulutuksen kansansivistystehtävä on luonut maaperän kasvatuksen elämänkatsomuksellisen tehtävän korostamiselle. Humanistinen psykologia tarjoaa tunnustuksellisuudesta vapaan elämänkatsomuksellisen vaihtoehdon ja voi siksi olla vetoava. Aikuiskasvatusintituutioilla on taipumus omaksua Maslowin ja Jungin kirjoituksista omaksuttujen kaltaisia ajatuksia ja termejä voidakseen kilpailla kaupallisten onnellistamis- ja menestyskurssien kanssa. Ongelmana on tuolloin kriittisen tutkimuksen ja ihmisten neuvottomuutta ja toiveita paremmasta taloudellisesti hyödyntävien oppien rajojen hämärtyminen. Tällaista sekoittumista on nähtävissä aikuiskoulutuksen kentässä. Elämäntaidon ja henkisen kasvun kurssit ovat syrjäyttäneet perinteiset akateemiset ja harrastusaineet kesäyliopistoissa. Samassa koulutusilmoituksessa markkinoidaan avoimen yliopiston kursseja ja kursseja nimeltään "kohtaa lohikäärmeesi", "myönteisyyden mahtava voima" "NLP (perus ja jatko)" sekä "kohtaa sisäinen lapsesi" (Helsingin aikuisopisto, HS 10.1.1999). Tämä rajojen hämärtyminen ja sulautuminen voi murentaa myös aikuiskasvatustieteen asemaa. Näin tapahtuu, jos se avaa ovensa konsultti- ja kaupallisiin tarkoituksiin muokatuille näkemyksille ja opeille sen sijaan että se tieteen tradition mukaisesti arvioisi kriittisesti lähtökohtiensa teoreettisia ja yhteiskunnallisia perusteita.

\section{Lähteet}

ALLPORT, G. (1950) Motivation in personality: Reply to Mr. Bertocci. Psychological Review 47 (6), 533-554.

COLE, M. (1996) Cultural Psychology. A once and future discipline. Cambridge, Mass. : The Belknap Press.

ENGESTRÖM, Y. (1995) Kehittävä työntutkimus. Perusteita, tuloksia, haasteita. Helsinki: Valtion Painatuskeskus

ENGESTRÖM, Y. \& Miettinen, R. \& Punamäki, R-L (1999) Perspectives on Activity Theory. Cambridge, Mass.: Cambridge University Press.

GOLDSTEIN, K. (1947) Organismic approach to the problem of motivation. Transactions of New York Academy of Science 9, 218-230.

GOLDSTEIN, K. (1995) The organism. New York: Zone Books

HAEKEL, E. (1912) Maailmanarvoitukset. Yleistajuisia tutkielmia monistisen filosofian alalta. Pori Osuuskunta Kehitys

HOLT, N. (1971) Ernst Haeckel's monistic religion. Journal of the History of Ideas 32(2), 265-280

JUNG, C. G. (1920) Instinct and the unconscious. The British Journal of Psychology 10, 15-23

JUNG, C.G. (1933) Modern man in search of a soul London: Routledge \& Keagan

JUNG, C.G. (1938) Psychology and religion. New Haven: Yale University press

JUNG, C.G. (1958) The undiscoved self. New York Penguin

JUNG, C.G. (1960) Nykyhetki ja tulevaisuus. Helsinki Kirjayhtymä

JUNG, C.G. (1966) Piilotajunnan psykologia. Helsinki: Tammi

JUNG, C.G. (1983) The essential Jung. Edited and introduced by Anthony Storr. Princeton: Princeton University Press

JUNG, C.G. (1991) Kohti totuutta. Poleemisia esseitä. Juva: WSOY

JUNG, C.G. (1995) Unia, ajatuksia ja muistikuvia Porvoo:WSOY

KOLB, D, (1984) Experiential learning. Experience as the source of learning and Development. Englewood Cliffs, NJ: Prentice Hall

MASLOW A. (1951) Higher needs and personality. Dialectica 5, 257-265

MASLOW, A.H. (1955) Deficiency motivation and growth motivation. In Jones, M.R. (ed.) Nebarska Symposium on Motivation. Lincoln, 1-30

MASLOW, A.H. (1959) Psychological data and value theory. Teoksessa Maslow, A. \& Sorokin, P.A (toim.) New knowledge in human values. New York: Harper \& Row, 119-136

MASLOW, A. H. (1961a) Peak experiences as acute identity experiences. The American Journal of Psychoanalysis 21 (2), 254-263

MASLOW, A. H. (1961b) Eupsychia - the good society Journal of Humanistic Psychology 1(2), 1-11

MASLOW, A.H. (1962a) Notes on being-psychology Journal of Humanistic Psychology 2(2), 47-71.

MASLOW, A.H. (1962b) Lessons from the peak-experiences. Journal of Humanistic Psychology 2 (1), 9-18

MASLOW, A.H. (1964) Synergy in the society and in 
individual. Journal of Individual Psychology 20 153-164.

MASLOW, A.H. (1965) Eupsychian management. Homewood, Illinois: Richard D. Irwin.

MASLOW, A.H. (1969) Various meanings of transcendence. The Journal of Transpersonal Psychology 20, 56-66.

MASLOW, A.H. (1970) Motivation and personality. New York: Harper \& Row.

MASLOW, A.H. (1976) A theory of metamotivation: A biological rooting of value-life. In Maslow, A.H The farther reaches of human nature. Harmontswoth: Penguin, 289-328.

MASLOW, A.H. (1994) Religions, values and peak-experiences. New York: Penguin.

McDOUGALL, W. (1912) An introduction to social psychology. London: Methuen \& Co.

NOLL, R. (1996) The Jung cult. Origins of a charismatic movement. London: Fontana Press.

NOLL, R. (1997) The Arayan Crist. The secret life of Carl Jung. New York: Tandom House.

RAUHALA, L. (1990) Humanistinen psykologia. Helsinki: Yliopistopaino.

ROGERS, C. (1979) Freedom to learn. Columbus, Ohio: Charles E. Merril

SASS, L. A. (1989) Humanism, hermeneutics, and humanistic psychoanalysis: different conceptions of subjectivity. Psychoanalysis and Comtemporary Thought 12(3), 433-503.

TAYLOR, C. (1989) Sources of self. The making of modern identity. Cambridge, Mass: Harvard University Press.

TAYLOR, C. (1991) The ethics of authentity. Cambridge, Mass: Harvard University Press.

WENGER, E. (1998) Communities of practice. Learning, meaning and identity. Cambridge: Cambridge University Press

WERTHEIMER, M. (1978) Humanistic psychology and the humane but tough-minded psychology. American Psychologist, August 1978, 739-745.

WILSON, C. (1972) New pathways in psychology. Maslow \& the Post-Freudian revolution. London Victor Collancz.

WOLLMAN, B. B. (1960) Contemporary theories and systems of psychology. New York: Harper \& Brothers.

\section{Viitteet}

1 Myös tätä selittävää universaalitendenssiä voi pitää keinotekoisena. Modernille paleoantropologialle riittää sen toteaminen, että kielen ja kulttuurin omaksumisen anatomiset ja hermostolliset ehdot ovat kehittyneet ihmistymisen vuosimiljoonien kuluessa - vuorovaikutteisesti kulttuurin muotojen kanssa (esim. Geerz 1973, Lumsden \& Wilson 1983). Yksilön kehitys itsessään on riippuvainen siitä kulttuurista, jonka yksilö sosialisaatiossaan omaksuu ja jonka kehittämiseen hän osallistuu.

2 Olemisarvojen pohjalta Maslow kehitti mallin parem masta "eypsykiaanisesta" (Maslow 1961b) tai "korkean synergian" yhteiskunnasta (Maslow 1964) sekä eypsykiaanisen johtamisteorian organisaatioiden kasvun optimoimiseksi (Maslow 1965).
3 B-arvojen eli olemisarvojen (Maslow 1962a, 5455) määritelmät ovat sananmukaisesti satojen adjektiivien luetteloita. 14 perusarvoa ovat: 1) totuus, 2) hyvyys, 3) kauneus, 4) kokonaisuus (wholeness) ja dikotomioiden ylittäminen, 5) eloisuus, 6) ainutkertaisuus, 8) täydellistyminen ja välttämättömyys, 9) oikeudenmukaisuus ja järjestys, 10) yksinkertaisuus, 11) rikkaus, 12) vaivattomuus, 13) leikkisyys, 14) itseriittoisuus. Kukin sana määritelään uudella sanalistalla. Niinpä arvo 13, leikkisyys on hauskaa, iloa, huumoria jne.. Tuloksena on noin 150:n hyviä asioita ilmaisevan sanan ja määreen lista.

4 Teoksensa Religions, values and peak experiences johdannossa Maslow toteaa, että kirkot ovat muuttumassa byrokraattisiksi, mikä uhkaa tukahduttaa aidon uskonnollisen kokemuksen (1994, viii): "Mystinen kokemus, valaistuminen, suuri herääminen ja koko se karismaattinen näkijyys, joka aloitti koko asian, on unohtumassa, katoamassa tai kääntymässä vastakohdakseen. Organisoitu uskonto, kirkot, saattavat lopulta tulla uskonnollisen kokemuksen ja kokijan päävihollisiksi. Tämä on kirjani pääteesi."

5 Maslow kuvaa empiiristä, havaintojen (1961, 254): "Huippukokemus on tässä yhteydessä nimi, sana, käsite, joka ilmaisee samanlaisuutta, joka on rakkauden, luovuuden, orgasmin, synnytys- ja mystisellä (oseaanisella, kosmisella) kokemuksella, tietyillä urheilu- ja esteettisillä ja eräillä muilla kokemuksilla. $\mathrm{Ne}$ ovat tietenkin henkilökohtaisia ja subjektiivisia kokemuksia, mutta minä kuuntelijana voin havaita samankaltaisuutta kaikkien näiden kokemuksien, josta sitten voin tehdä abstraktin yleistyksen."

6 Näitä teoksia ovat mm. Modern man in search of O soul (1938), Undiscoved Self (1958) sekä suomennettu Nykyhetki ja tulevaisuus (1960).

7 1800-luvun saksalaisesta romanttisesta luonnon filosofiasta maailmankuvana ja Haeckelin monistisesta uskonnosta, katso Holt 1971.

Q "Viittaan sellaisten synnynnäisten psyykkisten il 8 miöiden kuin vietit ja mieltämisen arkkityypit kokonaisuuteen sanoilla "kollektiivinen piilotajunta (Jung 1920, 19)"."Tätä ei-persoonallista psyyken kerrostumaa kutsun kollektiiviseksi piilotajunnaksi "kollektiiviseksi", koska se ei ole yksilön hankkimaa, vaan on pikemminkin perityn aivorakenteen toimintaa, jonka rakenne on pääpiirteissään samanlainen kaikilla ihmisillä, ja tietyissä suhteissa sama kaikilla nisäkkäillä (Jung 1991,177)."

9 Humanistisen psykologian kattava käsittely vaa isi myös fenomenologis-eksistentaalisten (esim. Rauhala 1990) ja uuspsykoanalyyttisten käsitysten (esim. Sass 1989) esittelyä ja arviointia.

Artikkeli saapui toimitukseen 3.2.1999 ja hyväksyttiin julkaistavaksi 25.3.1999. 